ticularly the Ferruginous) and a Golden Eagle. For the birder from England, this short hour of observation from Jones' Peak revealed the characteristic bird life of that dramatic eroded valley terrain.

\section{SAW WHET OWL ATTACKS ROBIN}

SANDRA JOHNS

\#4-14936 56 Avenue,

Edmonton, Alberta T6H 4X9

On April 20, 1977 I was conducting a lonely vigil at a Saw whet Owl nest on the Wagner property, a sprucetamarack bog on 118 Avenue on the outskirts of Edmonton, Alberta. A male Ruffed grouse was drumming close by, a coyote walked in the forest within 20 feet of me, and two robins were singing in the area.

At 2023, while still fairly light, the Saw whet male arrived, calling softly, and sat in a tree 15 feet behind me, directly facing the nest (about 30 feet away). The male transferred prey from foot to beak, flew to the nest, calling softly, and deposited food in the nest hole.

The bird returned to his original perch and called territorially for a few seconds. One of the robins landed in a tree a few feet from the nest, then flew to a tree, 60 feet east of the nest.

Suddenly, the male owl took off from his perch, flew at the singing robin and struck it with his talons. The robin, screeching loudly, flew over me and away from the area. The owl disappeared into the bushes. No robin sang for the rest of the evening. It was a most dramatic incident.

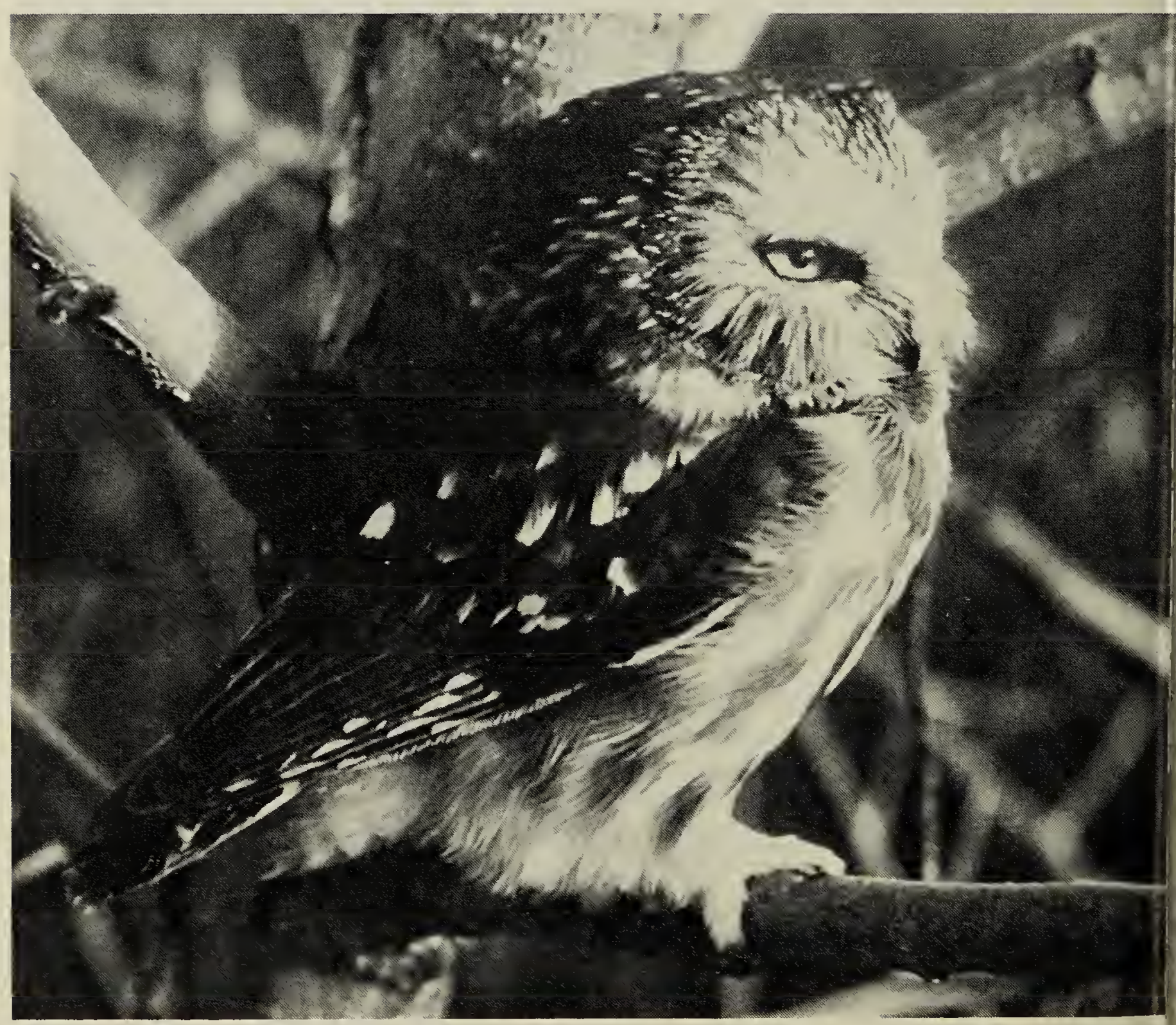

